\title{
Space-Time Distribution of the Ichthyofauna from Saco da Fazenda Estuary, Itajaí, Santa Catarina, Brazil
}

\author{
João Pedro Barreiros ${ }^{\dagger}$, Joaquim Olinto Branco ${ }^{\ddagger}$, Felipe Freitas Júnior ${ }^{\ddagger}$, Leonardo Machado ${ }^{\dagger}$, \\ Mauricio Hostim-Silva ${ }^{\ddagger}$, and José Roberto Verani ${ }^{\S}$
}

Universidade dos Açores

Departamento Ciências Agrárias and IMARAçores

9701-851 Angra do Heroísmo, Portugal
*Centro de Ciências Tecnológicas, da Terra e do Mar-CTTMar

Universidade do Vale do Itajaí

Caixa Postal 360, 88301-970 Itajaí, SC, Brasil

\author{
§Universidade Federal de São Carlos \\ Caixa Postal 676 \\ 13565-905 São Carlos, SP, Brasil
}

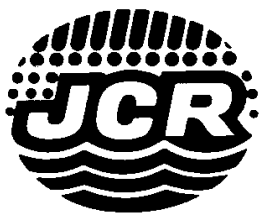

ABSTRACT
BARREIROS, J.P.; BRANCO, J.O.; FREITAS, F., JR.; MACHADO, L.; HOSTIM-SILVA, M., and VERANI, J.R., 2009.
Space-time distribution of the ichthyofauna from Saco da Fazenda Estuary, Itajaí, Santa Catarina, Brazil. Journal Space-time distribution of the ichthyofauna from Saco da Fazenda Estuary, Itajaí,
of Coastal Research, 25(5), 1114-1121. West Palm Beach (Florida), ISSN 0749-0208.

From July 2003 to June 2004, the physiographic characteristics of the ichthyofauna of the estuary of Saco da Fazenda were studied in four defined areas representative of the estuary. A total of 4502 individuals were captured, with 42 species, 35 genera, and 21 families. Engraulidae were the most abundant fish, and Cetengraulis edentulus dominated the captures. The species of occasional occurrence prevailed in the samplings and were represented mainly by juvenile individuals. The highest abundances occurred during the months of summer and autumn, in contrast with high biomasses in the spring and autumn; area IV contributed the largest captures. The richness indexes, diversity, and equitability presented similar flotation patterns, with high values in spring and summer. The Jaccard index revealed a greater similarity in the composition of the ichthyofauna in areas II and IV, while the lowest happened between I and IV, which is probably due to the different sizes of these areas.

This paper clearly shows the relevance of this estuary, albeit strongly impacted, for recruitment of small fish mainly during summer and autumn months.

ADDITIONAL INDEX WORDS: Abundance, diversity, richness, seasonal fluctuations.

\section{INTRODUCTION}

The distribution of fish assemblages is closely related to environmental parameters such as salinity, temperature, turbidity, and dissolved oxygen (Ansari et al., 1995; Barletta et al., 2005; Garcia and Vieira, 1997; Marshal and Elliott, 1997; Vivier and Cyrus, 2002). In tropical environments, salinity mostly acts on the number of species while in temperate estuaries, temperature is normally regarded as the key factor that causes a reduced richness (Vieira and Musick, 1993).

In Brazil, most studies dealing with estuarine fish assemblages were made in Rio de Janeiro (Andreata et al., 1990, 2002; Araújo et al., 1998, 2001; Brum et al., 1994; Costa, 1984; Pessanha et al., 2000), Paraná (Chaves and Bouchereau, 1999a, 1999b; Chaves and Corrêa, 1998; Neto et al., 2004; Santos et al., 2002; Spach, Santos, and Godefroid, 2003; Spach et al., 2004; Vendel et al., 2002), Rio Grande do Sul (Chao et al., 1982; Garcia and Vieira, 1997, 2001; Godefroid et al., 2004; Pereira, 1994; Silva, 1982) and in some areas of the north states (Araújo, Teixeira, and Oliveira, 2000; Camargo and Isaac, 2001; Castro, 2001; Lopes, Oliveira-Silva, and Ferreira-Melo, 1998; Vasconcelos-Filho and Oliveira, 1999). Although Santa Catarina's coast has a fair number of important estuaries, their fish assemblages have been seldom

DOI: 10.2112/08-1050.1 received 30 July 2008; accepted in revision 1 August 2008. studied (Hostim-Silva et al., 2002). Nevertheless, work was done on the lagoon complex of Laguna (Monteiro-Neto et al., 1990), the mangroves of Itacorubi (Florianópolis) (Clezar, Hostim-Silva, and Ribeiro, 1998), the Camboriú river estuary (Balneário Camboriú) (Rodrigues et al., 1994), Babitonga Bay (São Francisco do Sul) (Hostim-Silva et al., 1998), and the mouth of the Itajaí-Açú river (Itajaí) (Hostim-Silva et al., 2002).

Because of the importance of Saco da Fazenda's estuary and the lack of both qualitative and quantitative data on this ecosystem and its fish assemblage (no studies published on fish ecology), we projected and developed the present work to obtain a primary analysis of spatial and temporal variations of its ichthyofauna. The region is highly threatened by several development processes, such as industrial ports and factories, which also imply increased pollution. This estuary is probably also important for larval and postlarval development.

\section{MATERIALS AND METHODS}

Collections were made on a monthly basis between June 2003 and June 2004 in Saco da Fazenda's estuary, Itajaí, SC, Brazil (26 $\left.53^{\prime} 33^{\prime \prime}-26^{\circ} 55^{\prime} 06^{\prime \prime} \mathrm{S}, 48^{\circ} 38^{\prime} 30^{\prime \prime}-48^{\circ} 39^{\prime} 14^{\prime \prime} \mathrm{W}\right)$, in four previously chosen areas that are physiographically representative of the whole ecosystem (Figure 1). Our study area is strongly affected by several human activities, namely long 


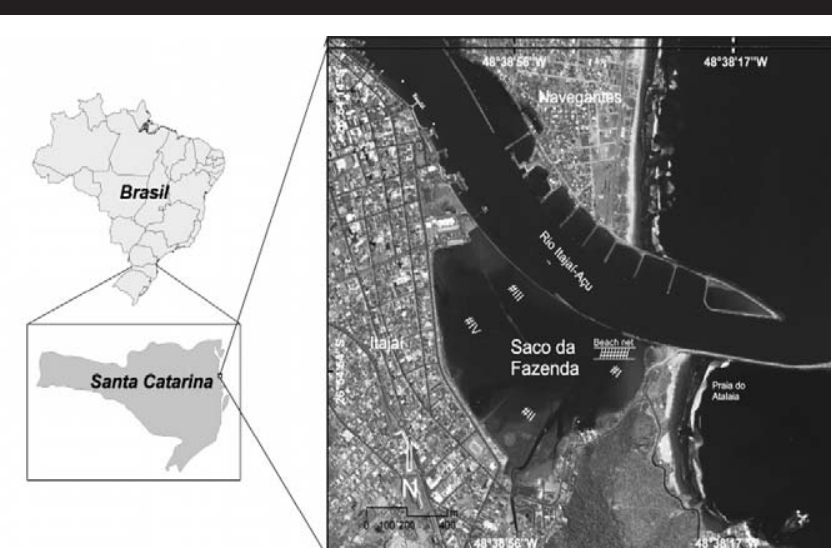

Figure 1. Satellite photograph of the study area. Saco da Fazenda, Itajaí, SC, Brazil. (Source: Google Earth.)

piers that advance the Itajaí-Açú river canal toward the ocean. This has resulted in the isolation of an ancient river meander. Water renewal is thus strongly restricted; the bottom substrate is typically composed of silt clay and the maximum depth is $2.0 \mathrm{~m}$ (while in the canals that connect it to the river the depth reaches $9.0 \mathrm{~m}$ ). Tidal amplitude is lower than $1.4 \mathrm{~m}$, and the average annual rainfall varies between 1250 to $1500 \mathrm{~mm}$ (Branco, 2000).

Fish were collected with a purse seine net (25-mm mesh) and a beach net (30 m long, with a central part made of 40 $\mathrm{mm}$ mesh and two lateral parts made of $400-\mathrm{mm}$ mesh) trawled by a rowboat. In each area 20 throws were made with the seine net while the beach net was kept underwater near the connection canal for periods of 4 hours followed by a 2-hour interval. Collected material was placed in identified plastic bags and kept in isothermal boxes with ice. In the laboratory, specimens were separated by species (Barletta and Corrêa, 1992; Figueiredo and Menezes, 1978, 1980, 2000; Menezes and Figueiredo, 1980, 1985); and grouped by families following Nelson (2006). The number of specimens and biomass per species were noted. Air and water temperatures as well as salinity were measured in every sampling trip, thus obtaining relevant data for later ecological analyses.

Eventual significant differences in environmental parameters, richness, number of individuals, biomass, diversity, and evenness between collection areas were tested by ANOVA (Zar, 1999) with complementary tests for variance homogeneity (Bartlett test) and normality of distribution (Kolmogorov-Smirnov). When significant differences appeared, the median contrast (Tukey-Kramer test) was applied to show which were significantly different.

Fish species were grouped in the following categories (Chaves and Bouchereau, 1999a; Felix et al., 2007) according to their percentage of occurrence: $0 \%-50 \%=$ occasional; $51 \%-75 \%=$ frequent, and $76 \%-100 \%$ common.

Indices of specific richness (Margalef, $D$ ), diversity (Shannon, $H^{\prime}$ ) and evenness (Pielou, $J^{\prime}$ ) were calculated monthly using the number of specimens per collection trip (Ludwig and Reynolds, 1988). Similarity between the study areas was estimated through the Jaccard index (Southwood, 1968). To-
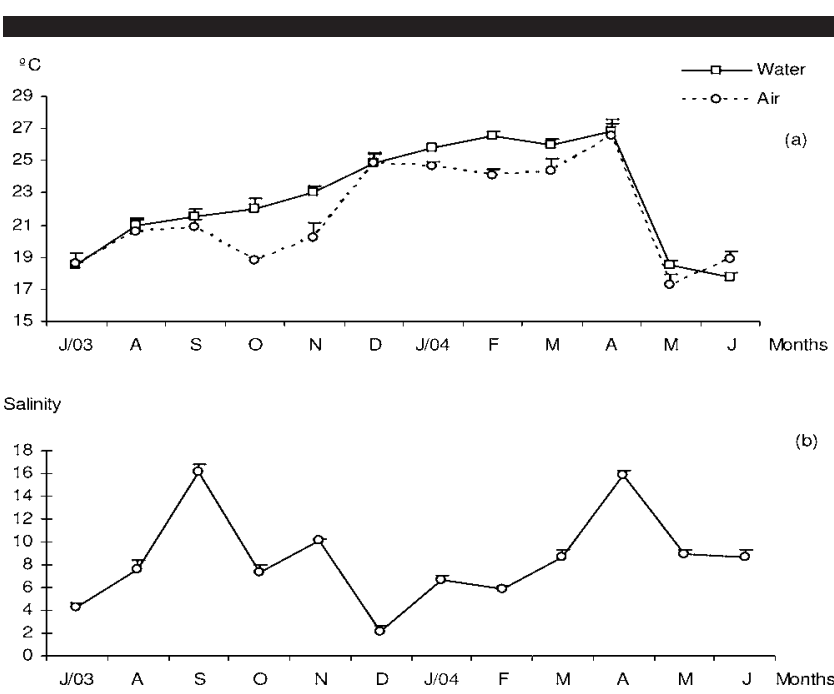

Figure 2. (a), (b) Average temporal variation of physicochemical parameters in the Saco da Fazenda estuary, Itajaí, SC, Brazil, between July 2003 and July 2004. (Vertical bar $=$ median error.)

tal biomass, total abundance, richness, diversity, and evenness were correlated (Spearman rank correlation, Statistica for Windows, v. 6.0) with air temperature, water temperature, and salinity.

To evaluate the adequacy of the sample size, we used the pooled quadrat method (Pielou, 1966) where the cumulative numbers of randomly pooled samples were plotted against the cumulative diversity. The Shannon Index (Magurran, 1988) was employed to measure the diversity as

$$
H^{\prime}=-\sum_{i=1}^{n} P i\left(\log _{e} P i\right)
$$

where $P i$ is the proportion of individuals of the $i$ th species. Because the cumulative diversity curves are based on random orders of quadrats, 1000 random orders of samples were calculated. The mean curve for each sample was then estimated and plotted. Each diversity curve was considered asymptotic if at least two previous values of the total sample diversity $\left(H^{\prime}\right)$ were in the range $H^{\prime} \pm 0.05 H^{\prime}$.

\section{RESULTS}

\section{Abiotic Factors}

Air and water average temperatures showed a typical seasonal pattern and did not significantly differ between collection sites $\left(F_{3-40}=0.083, p \geq 0.05\right.$ and $F_{3-40}=0.052, p \geq 0.05$, respectively). Average water temperatures were highest in January and April $\left(24.6^{\circ} \mathrm{C}\right.$ and $26.6^{\circ} \mathrm{C}$ respectively) and lowest in May $\left(17.3^{\circ} \mathrm{C}\right)$ and June $\left(17.8^{\circ} \mathrm{C}\right)$ (Figure 2a). Water temperature showed a highly significant positive correlation with total fish abundance $(p=0.01)$ and a significant correlation with total biomass $(p=0.04)$.

Salinity was also not different between sampling areas $\left(F_{3-40}=0.161 ; p \geq 0.05\right)$. Nevertheless, the highest average values occurred in September (16.1) and April (15.9), and the lowest ones in December (2.1) (Figure 2b), showing a positive 


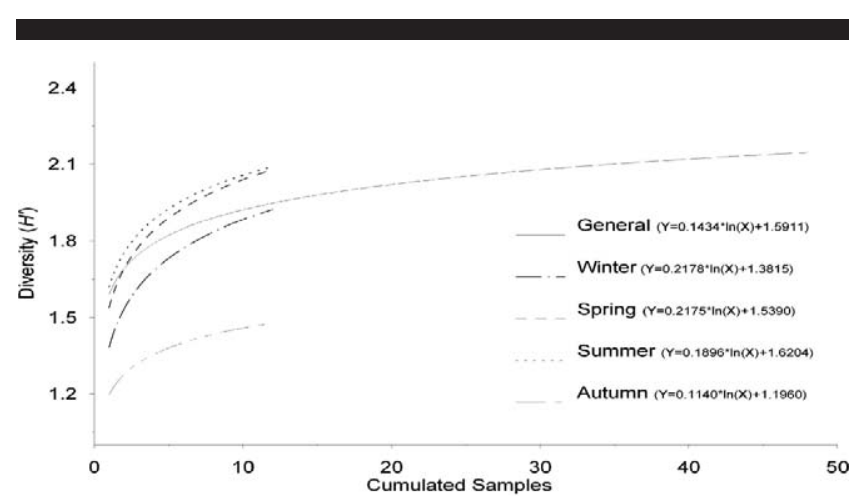

Figure 3. Cumulative diversity curves from all samples in the Saco da Fazenda estuary, Itajaí, SC, Brazil.

significant correlation with total fish abundance $\left(r_{s}=0.4153\right.$; $p<0.01$.

\section{Ichthyofauna Description}

The total number of unit samples analyzed to describe the ichthyofauna of Saco da Fazenda appears to be sufficient because all samples reached an asymptote (at least two values of total sample $H^{\prime}$ were in the range $H^{\prime} \pm 0.05$ ) (Figure 3).

During the sampling period, 4502 fish were collected belonging to 21 families, 35 genera, and 42 species (Table 1). Of these, 15 species occurred in all sampling sites. Eight families corresponded to the highest abundances (96.96\% of total fish). The most common families were: Engraulidae (37.72\%), Mugilidae (34.01\%), Gerreidae (16.84\%), and Clupeidae (7.44\%) (Table 1). Cetengraulis edentulus (Cuvier, 1829) was the dominant species representing $30.96 \%$ of the total abundance, followed by Mugil curema (Valenciennes, 1836) (27.57\%), Eucinostomus melanopterus (Bleeker, 1863) (7.71\%), Diapterus rhombeus (Cuvier, 1829) (7.37\%), Harengula clupeola (Cuvier, 1829) (7.00\%), Mugil platanus (Günther, 1880) (6.26\%), and Lycengraulis grossidens (Agassiz, 1834) (2.75\%) (Table 1).

Occasional species dominated all sampled sites with the highest frequencies in site I $(88.00 \%)$, followed by sites III $(84.00 \%)$, IV $(76.00 \%)$, and II $(73.00 \%)$ (Table 1), while frequent species predominated in site III (12.00\%) and common species in site II (19.00\%) (Table 1).

Area IV produced the highest abundance of fish (2033), followed by areas I (1022), II (939), and III (508) (Table 1). In spite of some oscillations, the number of species per sample was not significantly different between sampling areas $\left(F_{3-44}\right.$ $=1.826 ; p \geq 0.05$ ), with greater occurrences in spring-summer and fewer in fall-winter (Figure 4), where area I contributes 32 species, followed by areas II (26), III (25), and IV (25) (Table 1).

\section{Spatial Variations and Temporal Changes of Abundance and Biomass}

The average monthly abundance of fish collected within the estuary remained relatively low during winter, spring, and early summer, increasing from March 2004 onward and peak-

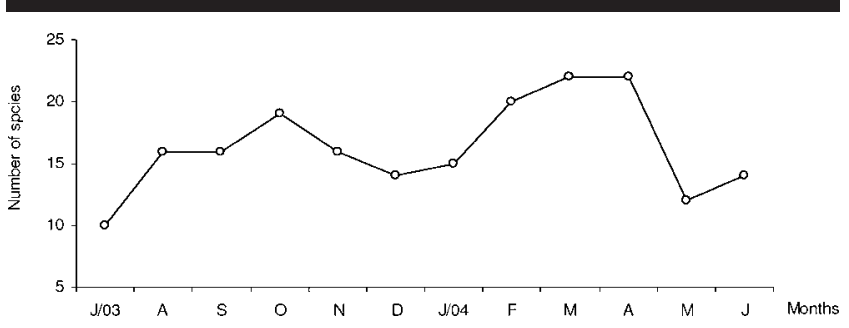

Figure 4. Variation in the number of species throughout the study period in the Saco da Fazenda estuary, Itajaí, SC, Brazil.

ing in April (212 \pm 85.91), followed by a fall in May (119 \pm $56.42)$ and another increase in June (165.25 \pm 79.23) (Figure $5)$. Significant differences $\left(F_{3-44}=4.291 ; p<0.05\right)$ were registered between the number of fish and sampling areas throughout the year and are due, according to Tukey-Kramer's test, to lower captures in site III when compared with higher ones from site IV (Table 1).

According to Figure 6, the highest average monthly biomass levels occurred during the spring-fall months, with annual peaks alternating between November $2003(2.57 \pm 0.92$ $\mathrm{kg})$, April 2004 (2.15 $\pm 0.69 \mathrm{~kg})$, and June $(2.18 \pm 0.84 \mathrm{~kg})$. Significant differences $\left(F_{3-44}=6.687 ; p<0.001\right)$ were observed between average biomass from the sampling sites. We attribute these differences to higher collections registered in site IV.

\section{Richness, Diversity, and Evenness}

Margalef's richness index $(D)$ showed higher values in site I (4.47), followed by sites III (3.85), II (3.65), and IV (3.15) (Table 1). No significant differences $\left(F_{3-44}=0.951 ; p \geq 0.05\right)$ were detected between monthly values of $D$ and sampling sites. Thus, higher average richness occurred in spring-summer months and lesser ones in fall-winter months (Figure 7).

Shannon-Wiener's diversity index $\left(H^{\prime}\right)$ did not differ significantly $\left(F_{3-44}=1.078 ; p \geq 0.05\right)$ between sampling sites, and the highest $H^{\prime}$ value was detected in site III (2.26), followed by sites II (2.09), I (1.99), and IV (1.68) (Table 1). When analyzing the average monthly changes in $H^{\prime}$ one may verify that higher values occurred also during spring-summer months, with peaks in October $(1.74 \pm 0.30)$ and March (1.83 \pm 0.25 ), and lesser values in the fall (May-0.90 \pm 0.20 ) (Figure 8).

Pielou's evenness index $\left(J^{\prime}\right)$, although moderately fluctuating between sampling sites, stayed statistically similar $\left(F_{3-44}=2.117 ; p \geq 0.05\right)$, with the higher annual value in site III (0.70), followed by sites II (0.64), I (0.57), and IV (0.52) (Table 1). Generally speaking, evenness followed the same tendency shown by $D$ and $H^{\prime}$ with higher values during spring-summer (peaking in October, February, and Marchall 0.76) while lower ones occurred in winter (May $=0.50 \pm$ 0.12) (Figure 9).

\section{Similarity}

Results achieved with Jaccard's index showed a relatively low level of similarity between our sampling sites. Values 
Table 1. Check list of fish species and their abundances between July 2003 to July 2004 in Saco da Fazenda's estuary, Itajaí, SC, Brazil. (Species occurrence is represented by: $>$ = common; $+=$ frequent; $<=$ occasional) (Nelson, 2006).

\begin{tabular}{|c|c|c|c|c|c|c|c|c|}
\hline Family/Species & Area I & Occ. & Area II & Occ. & Area III & Occ. & Area IV & Occ. \\
\hline \multicolumn{9}{|l|}{ Osteichthyes } \\
\hline \multicolumn{9}{|l|}{ Engraulidae } \\
\hline Cetengraulis edentulus (Cuvier, 1829) & 479 & $<$ & 172 & $>$ & 37 & $<$ & 706 & + \\
\hline Lycengraulis grossidens (Agassiz, 1834) & 103 & + & 3 & $<$ & 16 & + & 2 & $<$ \\
\hline \multicolumn{9}{|l|}{ Clupeidae } \\
\hline Opisthonema oglinum (Lesuer, 1818) & 4 & $<$ & & & 7 & $<$ & 2 & $<$ \\
\hline Harengula clupeola (Cuvier, 1829) & 130 & $<$ & 57 & + & 29 & $<$ & 99 & $<$ \\
\hline Sardinella brasiliensis (Steindachner, 1789) & & & & & 5 & $<$ & 2 & $<$ \\
\hline \multicolumn{9}{|l|}{ Ariidae } \\
\hline Genidens genidens (Valenciennes, 1848) & 17 & $<$ & 18 & $<$ & & & 5 & $<$ \\
\hline \multicolumn{9}{|l|}{ Mugilidae } \\
\hline Mugil curema (Valenciennes, 1836) & 57 & + & 284 & $>$ & 205 & $>$ & 695 & $>$ \\
\hline M. gaimardianus (Desmarest, 1831) & & & & & 7 & $<$ & 1 & $<$ \\
\hline M. platanus Günther, 1880 & 4 & $<$ & 39 & $>$ & 30 & $<$ & 209 & $>$ \\
\hline \multicolumn{9}{|l|}{ Atherinopsidae } \\
\hline Atherinella brasiliensis (Quoy and Gaimard, 1825) & 3 & $<$ & 4 & $<$ & 17 & $<$ & 13 & + \\
\hline \multicolumn{9}{|l|}{ Belonidae } \\
\hline Strongylura timucu (Walbaum, 1792) & & & & & 1 & $<$ & & \\
\hline \multicolumn{9}{|l|}{ Centropomidae } \\
\hline Centropomus parallelus Poey, 1860 & & & 4 & $<$ & & & 4 & $<$ \\
\hline Pomatomidae & & & & & & & & \\
\hline Pomatomus saltator (Linnaeus, 1758) & 2 & $<$ & 1 & $<$ & 2 & $<$ & & \\
\hline Carangidae & & & & & & & & \\
\hline Caranx latus Agassiz, 1831 & 2 & $<$ & 1 & $<$ & & & & \\
\hline Selene setapinnis (Mitchill, 1815) & & & 1 & $<$ & 1 & $<$ & & \\
\hline S. vomer (Linnaeus, 1758) & 1 & $<$ & & & & & 1 & $<$ \\
\hline Chloroscombrus chrysurus (Linnaeus, 1766) & 1 & $<$ & & & 9 & $<$ & & \\
\hline Oligoplites saliens (Bloch, 1793) & 25 & $<$ & 11 & $<$ & 28 & $<$ & 3 & $<$ \\
\hline Oligoplites saurus (Bloch and Schneider 1801) & & & 1 & $<$ & & & 2 & $<$ \\
\hline Trachinotus falcatus (Linnaeus, 1766) & & & & & & & 2 & $<$ \\
\hline Gerreidae & & & & & & & & \\
\hline Eucinostomus argenteus (Baird and Girard, 1854) & 22 & $<$ & 8 & $<$ & 14 & $<$ & 14 & $<$ \\
\hline E. melanopterus (Bleeker, 1863) & 70 & $>$ & 151 & $>$ & 46 & + & 80 & $>$ \\
\hline E. gula (Cuvier, 1830) & 9 & $<$ & 4 & $<$ & 2 & $<$ & 6 & $<$ \\
\hline Diapterus rhombeus (Cuvier, 1829) & 27 & $<$ & 109 & $>$ & 32 & + & 164 & $>$ \\
\hline Haemulidae & & & & & & & & \\
\hline Conodon nobilis (Linnaeus, 1758) & 6 & $<$ & & & 7 & $<$ & & \\
\hline Sciaenidae & & & & & & & & \\
\hline Micropogonias furnieri (Desmarest, 1823) & 18 & + & 6 & $<$ & 5 & $<$ & 4 & $<$ \\
\hline Cynoscion leiarchus (Cuvier, 1830) & 1 & $<$ & & & & & & \\
\hline Stellifer rastrifer (Jordan, 1889) & 5 & $<$ & & & & & & \\
\hline S. stellifer (Bloch, 1790) & 1 & $<$ & & & & & & \\
\hline Bairdiella ronchus (Cuvier, 1830) & 15 & $<$ & & & & & & \\
\hline Cichlidae & & & & & & & & \\
\hline Geophagus brasiliensis (Quoy and Gaimard, 1824) & 8 & $<$ & 50 & + & 2 & $<$ & 9 & $<$ \\
\hline Oreochromis niloticus (Linnaeus, 1758) & & & 2 & $<$ & & & 3 & $<$ \\
\hline Blenniidae & & & & & & & & \\
\hline Hypleurochilus fissicornis (Quoy and Gaimard, 1824) & 1 & $<$ & & & & & & \\
\hline Gobiidae & & & & & & & & \\
\hline Gobioides braussonnetii Lacépède, 1800 & & & 1 & $<$ & & & & \\
\hline Bathygobius soporator (Valenciennes, 1837) & 2 & $<$ & 1 & $<$ & & & & \\
\hline Gobionellus oceanicus (Pallas, 1770) & 2 & $<$ & 2 & $<$ & 1 & $<$ & & \\
\hline Scombridae & & & & & & & & \\
\hline Scomberomorus brasiliensis Collette, Russo, and Zavala-Camin, 1978 & 2 & $<$ & & & 1 & $<$ & & \\
\hline Paralichthyidae & & & & & & & & \\
\hline Citharichthys spilopterus (Günther, 1862) & 2 & $<$ & 4 & $<$ & 3 & $<$ & 4 & $<$ \\
\hline Achiridae & & & & & & & & \\
\hline Achirus lineatus (Linnaeus, 1758) & 1 & $<$ & 4 & $<$ & 1 & $<$ & 1 & $<$ \\
\hline Cynoglossidae & & & & & & & & \\
\hline Symphurus tessellatus (Quoy and Gaimard, 1824) & 1 & $<$ & & & & & & \\
\hline Tetraodontidae & & & & & & & & \\
\hline Lagocephalus laevigatus (Linnaeus, 1766) & 1 & $<$ & & & & & & \\
\hline Diodontidae & & & & & & & & \\
\hline Chilomycterus spinosus spinosus (Linnaeus, 1758) & & & 1 & $<$ & & & 2 & $<$ \\
\hline Total fish & 1022 & & 939 & & 508 & & 2033 & \\
\hline Total species & 32 & & 26 & & 25 & & 25 & \\
\hline No occasional species & 28 & & 19 & & 21 & & 19 & \\
\hline No frequent species & 3 & & 2 & & 3 & & 2 & \\
\hline No common species & 1 & & 5 & & 1 & & 4 & \\
\hline Richness $D$ & 4.47 & & 3.65 & & 3.85 & & 3.15 & \\
\hline Shannon-Wiener's diversity $H^{\prime}$ & 1.99 & & 2.09 & & 2.26 & & 1.68 & \\
\hline Pielou's evenness $J^{\prime}$ & 0.57 & & 0.64 & & 0.70 & & 0.52 & \\
\hline
\end{tabular}




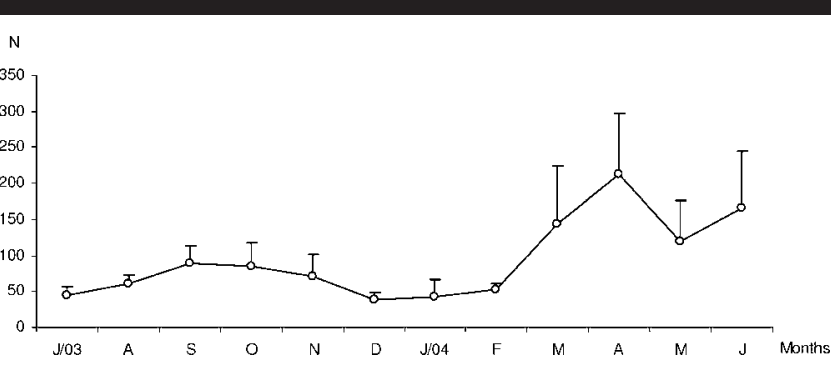

Figure 5. Monthly variation of the average number of fish collected in the Saco da Fazenda estuary, Itajaí, SC, Brazil, between July 2003 and July 2004. (Vertical bar $=$ median error.)

varied between $46.15 \%$ and $64.25 \%$. Highest faunistic similarity was found between sites II and IV (64.25\%), followed by the groupings I and III (58.33\%), III and IV (56.25\%), III and II $(54.55 \%)$, I and II $(52.63 \%)$, and the lowest one between the groupings I and IV (46.15\%).

\section{DISCUSSION}

Seasonal changes in the abundance of estuarine fish have been attributed to both water temperature and salinity (Hagan and Able, 2003; Pereira, 1994; Pessanha et al., 2000; Santos et al., 2002; Spach, Santos, and Godefroid, 2003; Vendel et al., 2000, 2003). According to Marshall and Elliot (1997) and to Hagan and Able (2003), temperature was considered to be the main cause of variation in the number of species occurring in a given moment. Alternatively, Pessanha et al. (2000) and Vendel et al. (2003) attribute these variations to food availability inside estuaries (a fact that may well be directly dependent on the previously discussed abiotic factors). Laffaille, Feunteun, and Lefeuvre (2000) and Ikejima, Tongnunui, and Taniuchi (2002), also refer to factors such as reproductive periods, mortality rates, and species migration patterns as the main factors that are decisive in a community's species composition and abundance.

In Saco da Fazenda's estuary, the occurrence of larvae in summer, coming straight from the nearby oceanic environment and clearly associated with higher summer and early fall temperatures, together with higher food availability, may well have been a major contributor to our increasing abun-

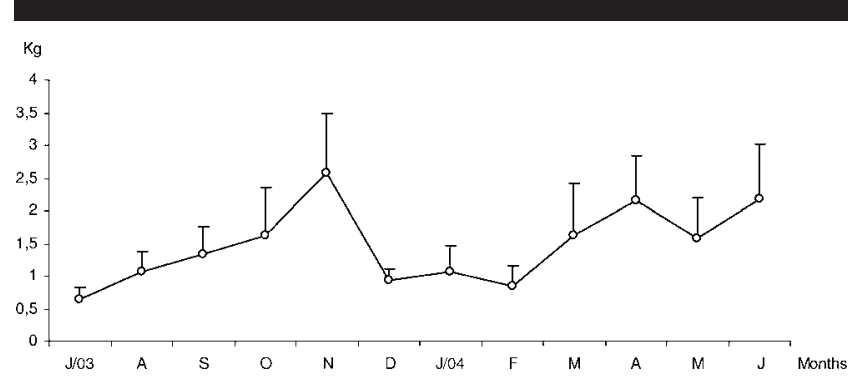

Figure 6. Monthly variation of the average biomass of fish collected in the Saco da Fazenda estuary, Itajaí, SC, Brazil, between July 2003 and July 2004. (Vertical bar $=$ median error.)

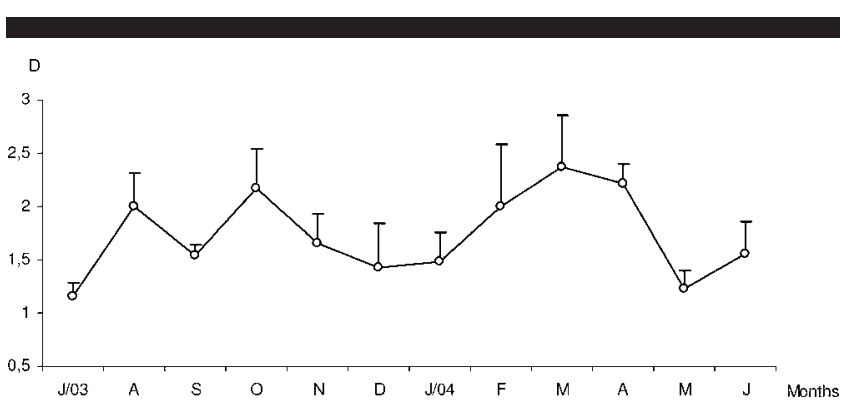

Figure 7. Monthly variation of average richness $(D)$ in the Saco da Fazenda estuary, Itajaí, SC, Brazil, between July 2003 and July 2004. (Vertical bar $=$ median error.)

dances in spring-summer months. Biomass showed a similar pattern, albeit higher weights are obtained during spring-fall months.

The significant differences obtained in both abundance and biomass between the sampling sites may well be due to the presence of both macrophytes and mangrove vegetation in site IV. According to Garcia and Vieira (1997), estuaries with important densities of aquatic vegetation offer a highly suitable habitat for larval development and juvenile nurseries, minimizing predation and increasing food sources. Besides this well-known aspect, in our area considerable amounts of domestic sewage discharges do occur, thus increasing the nutrient input to plants and primary consumers, all important food items for Mugilidae (Araújo-Silva and Araújo, 2000), a group abundantly collected during our study.

Margaleff's index $(D)$ of seasonal fluctuations was also verified by Vendel et al. (2002) in the fish community of Gamboa do Baguaçú (PR, Brazil). However, the greater richness of that region may be due to the size of the estuary, higher habitat diversity, and the nearness of adjacent coastal environments (Tongnunui et al., 2002). Although not significantly different, higher $D$ values shown in site I may be due to the number of occasional species that, according Vieira and $\mathrm{Mu}-$ sick (1993), are highly responsible for specific richness variations in tropical estuaries.

In our study, $H^{\prime}$ varied between 0.90 and 1.83; the lagoon complex of Laguna was found to be between 0.60 and 2.40 (Monteiro-Neto et al., 1990), Gamboa do Sucuri (Spach, San-

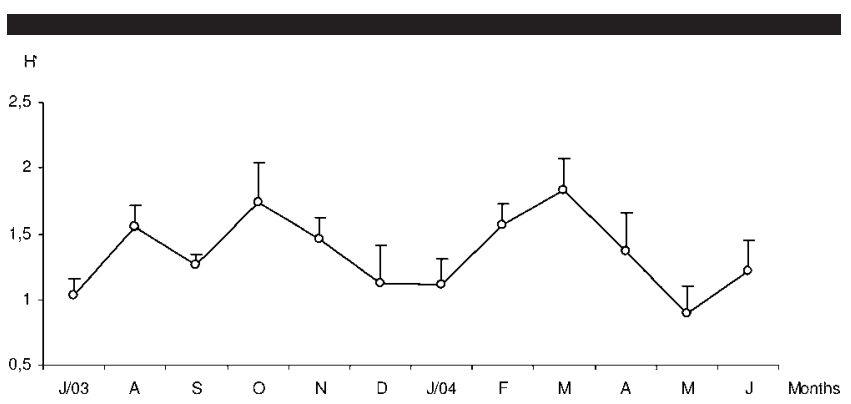

Figure 8. Monthly variation of average diversity $\left(H^{\prime}\right)$ in the Saco da Fazenda estuary, Itajaí, SC, Brazil, between July 2003 and July 2004. (Vertical bar $=$ median error. $)$ 


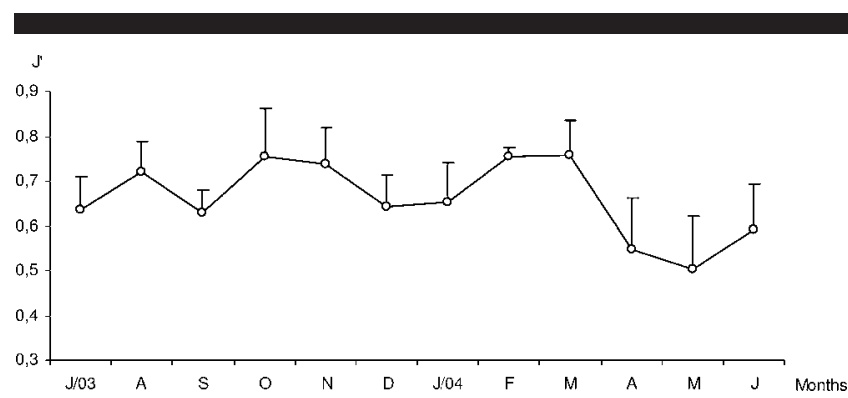

Figure 9. Monthly variation of average evenness $\left(J^{\prime}\right)$ in the Saco da Fazenda estuary, Itajaí, SC, Brazil, between July 2003 and July 2004. (Vertical bar $=$ median error.)

tos, and Godefroid, 2003) between 1.10 and 1.95, and Barra do estuário da Lagoa dos Patos between 1.20 and 2.27 (Pereira, 1994). Vieira and Musick (1993), state that these differences are probably related to temporal fluctuations in the abundance of resident species as well as the recruitment processes and opportunistic behavior of occasional species within each estuary.

Generally speaking, the higher diversity obtained during spring-summer months may be due to richness values and to a more proportional distribution of specimens during those periods. Using the same logic, we can attribute lesser diversities to a reduced number of species and to the strong dominance of both Mugil curema and Cetengraulis edentulus. This is something pointed out by Barreiros et al. (2004, 2005), while describing the ichthyofauna of adjacent oceanic waters about $60 \mathrm{~km}$ south of our study site. They especially note high increases of Engraulidae in spring-summer months. Although not significantly different, lower diversities in our site IV may reflect the region's instability caused by a low resistance by some species to high levels of domestic sewage inputs (see also Marshall and Elliot, 1997). This line of reasoning is also a probable explanation for the evenness variations detected.

Our fluctuations in $H^{\prime}, J^{\prime}$, and $D$ follow similar patterns as to the system's structural evaluation referred to by Castro (1997) in a study of the fish community of Barra Bonita, and by Benedito-Cecílio et al. (1997) in the Itaipú reservoir and adjacent areas.

Measures of similarity between habitats have been widely used when analyzing ichthyofauna stability together with studies on environmental influences and species occurrence that identify an ecosystem's discontinuities (Castro, 1997). In our study, the higher similarities obtained for sites II and IV are probably related to the presence of common species in the areas that are favored by abundant sheltering vegetation. In contrast, the similarity detected between sites I and III may be explained by the occurrence of occasional species coming straight from the Itajaí-Açú river, here functioning as a species "corridor." The piers from the central estuary area probably also act as a barrier between fish from areas I and IV, which may explain the low similarities found. These may also be a reflection of the instability caused by organic pollution in site IV, a factor that might well be deterrent for less tolerant species.

\section{ACKNOWLEDGMENTS}

The authors would like to thank the two identified referees for their comments and suggestions, substantially improving the previous version of the manuscript.

\section{LITERATURE CITED}

Andreata, J.V.; Barbiéri, L.R.R.; da Silva, M.H.C., and dos Santos, R.P., 1990. Relação dos peixes da Laguna de Marapendi, RJ, Brasil. Revista Atlântica, 12, 5-17.

Andreata, J.V.; Meurer, B.C.; Baptista, M.G.S.; Manzano, F.V.; Teixeira, D.E.; Longo, M.M., and Freret, N.V., 2002. Composição da assembléia de peixes da Baía da Ribeira, Angra dos Reis, RJ, Brasil. Revista Brasileira de Zoologia, 19, 1139-1146.

Ansari, Z.A.; Chatterfi, A.; Ingole, B.S.; Sreepada, R.A.; Rivonkar C.U., and Parulekar, A.H., 1995. Community structure and seasonal variation of inshore demersal fish community at Goa, west coast of India. Estuarine, Coastal and Shelf Science, 41, 417-430.

Araújo, F.G.; da Cruz-Filho, A.G.; de Azevedo, M.C.C., and dos Santos, A.C., 1998. Estrutura da comunidade de peixes demersais da Baía de Sepetiba, RJ, Brasil. Revista Brasileira de Biologia, 58, 417-430.

Araújo-Silva, M.A. and Araújo, F.G., 2000. Distribuição e abundância de tainhas e paratis (Osteichthyes, Mugilidae) na Baía de Sepetiba, RJ, Brasil. Revista Brasileira de Zoologia, 17, 473-480.

Araújo, M.E.; Teixeira, J.M., and de Oliveira, A.M.E., 2000. Ictiofauna marinha do estado do Ceará, Brasil: III. Actinopterygii de estuários. Arquivo de Ciências do Mar, 33, 139-142.

Araújo, F.G.; Fichberg, I.; Pinto, B.C.T., and Peixoto, M.G., 2001. Variações espaciais na assembléia de peixes no Rio Paraíba do Sul (Barra Mansa, Barra do Piraí), RJ, Brasil. Revista Brasileira de Zoologia, 18, 483-492.

Barletta, M.; Barletta-Bergan, A.; Saint-Paul, U., and Hubold, G., 2005. The role of salinity in structuring the fish assemblages in a tropical estuary. Journal of Fish Biology, 66, 45-72.

Barletta, M. and Corrêa, M.F.M., 1992. Guia para identificação de peixes da costa do Brasil. Curitiba, Brasil: Universidade Federal do Paraná, 113p.

Barreiros, J.P.; Hostim-Silva, M.; Figna, V., and Santos, R.S., 2004. Seasonal changes in a sandy beach fish assemblage at Canto Grande, Santa Catarina, South Brazil. Journal of Coastal Research, 20(3), 832-870.

Barreiros, J.P.; Figna, V.; Hostim-Silva, M., and Santos, R.S., 2005. Diel seasonality of a shallow-water fish assemblage at Canto Grande, Santa Catarina, Brazil. Journal of Coastal Research, Special Issue No. 42, pp. 343-347.

Benedito-Cecílio, E.B.; Agostinho, A.A.; Júlio, H.F., and Pavanelli, C.S., 1997. Colonização ictiofaunistica do reservatório de Itaipu e áreas adjacentes, PR, Brasil. Revista Brasileira de Zoologia, 14, 1 14.

Branco, J.O., 2000. Avifauna associada ao estuário do Saco da Fazenda, Itajaí, SC, Brasil. Revista Brasileira de Zoologia, 17, 384 394.

Brum, M.J.I.; Muratori, C.F.M.L.; Lopes, P.R.D., and Vianna, P.R.F.G., 1994. Ictiofauna do sistema lagunar de Marica, RJ. Acta Biológica Leopoldensia, 16(2), 45-55.

Camargo, M. and Isaac, V., 2001. Os peixes estuarinos da região Norte do Brasil: lista de espécies e considerações sobre sua distribuição geográfica. Boletim do Museu Paraense de História Natural e Ethnographia, 17, 133-157.

Castro, A.C.L., 1997. Aspectos ecológicos da comunidade ictiofaunística do reservatório de Barra Bonita, SP, Brasil. Revista Brasileira de Zoologia, 57, 665-676.

Castro, A.C.L., 2001. Diversidade da assembléia de peixes em Igarapés do estuário do rio Paciência (MA-Brasil). Revista Atlântica, 23, 39-46.

Chao, L.N.; Pereira, L.E.; Vieira, J.P.; Benvenuti, M.A., and Cunha, L.P.R., 1982. Relação preliminar dos peixes estuarinos e marinhos da Lagoa dos Patos e região costeira adjacente, RS, Brasil. Revista Atlântica, 5, 67-75. 
Chaves, P.T.C. and Bouchereau, J.L., 1999a. Biodiversité et dynamique des peuplementes ichtyiques de la mangrove de Guaratuba, Brésil. Acta Oceanologia, 22, 353-362.

Chaves, P.T.C. and Bouchereau, J.L., 1999b. Use of mangrove habitat for reproductive activity by the fish assemblage in the Guaratuba Bay, Brazil. Acta Oceanologia, 23(3), 273-280.

Chaves, P.T.C. and Corrêa, M.F.M., 1998. Composição ictiofaunística da área de manguezal da Baía de Guaratuba, PR, Brasil. Revista Brasileira de Zoologia, 15, 195-202.

Clezar, L.; Hostim-Silva, M., and Ribeiro, G.C., 1998. Comunidade de peixes do manguezal de Itacorubí, Ilha de Santa Catarina, SC, Brasil,. In: Soriano-Sierra, E.J. and Ledo, B.S. (eds.), Ecologia e Gerenciamento do Manguezal de Itacorubí. Florianópolis, Brasil: Universidade Federal de Santa Catarina, pp. 206-215.

Costa, W.J.E.M., 1984. Peixes fluviais do sistema lagunar de Marica, RJ, Brasil. Revista Atlântica, 7, 65-72.

Félix, F.C.; Spach, H.L.; Moro, P.S.; Schwarz, R., Jr.; Santos, C.; Hackradt, C.W., and Hostim-Silva, M., 2007. Utilization patterns of surf zone inhabiting fish from beaches in Southern Brazil. PanAmerican Journal of Aquatic Sciences, 2(1), 27-39.

Figueredo, J.L. and Menezes, N.A., 1978. Manual de peixes marinhos do Sudeste do Brasil. II. Teleostei (1). São Paulo: Museu de Zoologia da Univiversidade SP, 110p.

Figueredo, J.L and Menezes, N.A., 1980. Manual de peixes marinhos do Sudeste do Brasil. III. Teleostei (2). São Paulo: Museu de Zoologia da Univiversidade SP. 90p.

Figueredo, J.L and Menezes, N.A., 2000. Manual de peixes marinhos do Sudeste do Brasil. II. Teleostei (5). São Paulo: Museu de Zoologia da Univiversidade SP. 116p.

Garcia, A.M. and Vieira, J.P., 1997. Abundância e diversidade da assembléia de peixes dentro e fora de uma pradaria de Ruppia marítima L., no estuário da Lagoa dos Patos, RS, Brasil. Revista Atlântica, 19, 161-181.

Garcia, A.M. and Vieira, J.P., 2001. Aumento e diversidade de peixes no estuário da Lagoa dos Patos durante o episódio El Niño 19971998. Revista Atlântica, 23, 133-152.

Godefroid, R.S.; Spach, H.L.; Santos, C.; Maclaren, G., and Schwarz, R., Jr., 2004. Temporal changes in the abundance and diversity of the fish fauna in the shallow infralittoral of a beach, southern Brazil. Iheringia, Series Zoology, 94(1), 95-104.

Hagan, S.M. and Able, K.W., 2003. Seasonal changes of the pelagic fish assemblage in a temperate estuary. Estuarine, Coastal and Shelf Science, 56, 15-29.

Hostim-Silva, M.; Rodrigues, A.M.T.; Clezar, L.; Ribeiro, G.C., and Souza, M.A.C., 1998. Ictiofauna. In: Rodrigues, V.A.B. (ed.), Proteção e Controle de Ecossistemas Costeiros: manguezal da Baía da Babitonga. Brasília: Coleção Meio Ambiente IBAMA Série Estudos Pesca, vol. 25, pp.49-58.

Hostim-Silva, M.; Vicente, M.J.D.; Figna, V., and Andrade, J.P. 2002. Ictiofauna do Rio Itajaí Açu, Santa Catarina, Brasil. Notas Técnicas da Facimar, 6, 127-135.

Ikejima, K.; Tongnunui, P., and Taniuchi, T., 2002. Juvenile and small fishes in a mangrove estuary in Trang province, Thailand seasonal and habitat differences. Estuarine, Coastal and Shelf Science, 56, 447-457.

Laffaille, P.; Feunteun, E., and Lefeuvre, J.C., 2000. Composition of fish communities in a European macrotidal salt marsh (the Mont Saint-Michael Bay, France). Estuarine Coastal and Shelf Science, 51, 429-438.

Lopes, P.R.D.; Oliveira-Silva, J.T., and Ferreira-Melo, A.S.A., 1998 Contribuição ao conhecimento da ictiofauna do manguezal de Cacha Pregos, Ilha de Itaparica, Baía de todos os Santos, BA, Brasil. Revista Brasileira de Zoologia, 15, 315-325.

Ludwig, J.A. and Reynolds, J.F., 1988. Statistical Ecology: A Primer on Methods and Computing. New York: John Wiley, 338p.

Magurran, A.E., 1988. Ecological Diversity and Its Measurements. Princeton, New Jersey: Princeton University Press. $\mathrm{x}+179 \mathrm{p}$.

Marshall, S. and Elliott, M., 1997. Environmental influences on the fish assemblage of the Humber estuary, U.K. Estuarine, Coastal and Shelf Science, 46, 175-184.

Menezes, N.A. and Figueredo, J.L., 1980. Manual de peixes marin- hos do Sudeste do Brasil. IV. Teleostei (3). São Paulo: Museu de Zoologia da Univiversidade SP. 96p.

Menezes, N.A. and Figueredo, J.L., 1985. Manual de peixes marinhos do Sudeste do Brasil. V. Teleostei (4). São Paulo: Museu de Zoologia da Univiversidade SP. 105p.

Monteiro-Neto, C.; Blacher, C.; Laurente, A.A.S.; Snizek, F.N.; Canozzi, M.B., and Tabajara, L.L.C. de A., 1990. Estrutura da comunidade de peixes em águas rasas na região de laguna, SC, Brasil. Revista Atlântica, 12, 53-69.

Nelson, J.S., 2006. Fishes of the World. 4th edition. New York: John Wiley \& Sons, 600p.

Neto, J.F.O.; Godefroid, R.S.; Queiroz, G.M.L., and Junior, R.S. 2004. Variação diuturna na captura de peixes em planície de maré da Baía de Paranaguá, PR. Acta Biológica Leopoldensia, 26, 125138.

Pereira, L.E., 1994. Variação diurna e sazonal dos peixes demersais na barra do estuário da Lagoa dos Patos, RS, Brasil. Revista Atlântica, 16, 5-21.

Pessanha, A.L.M.; Araújo, F.G.; Azevedo, M.C.C., and Gomes, I.D., 2000. Variações temporais e espaciais na composição e estrutura da comunidade de peixes jovens da Baía de Sepetiba, RJ, Brasil. Revista Brasileira de Zoologia, 17, 251-261.

Pielou, E.C., 1966. The measurement of diversity in different types of biological collections. Journal of Theoretical Biology, 13, 131144.

Rodrigues, A.M.T.; Pereira, M.T.; Wegner, P.Z.; Branco, J.O.; Clezar, L.; Hostim-Silva, M., and Soriano-Sierra, E.J., 1994. Manguezal do Rio Camboriú: Preservação e controle da qualidade ambiental. Itajaí: IBAMA-CEPSUL, volume 13, 65p.

Santos, C.; Schwarz, R., Jr.; Oliveira-Neto, J.F., and Spach, H.L.A. 2002. A ictiofauna em duas planícies de maré do setor euhalino da Baía de Paranaguá, Pr, Brasil. Boletim do Instituto de Pesca, 28, 49-60.

Silva, C.P., 1982. Ocorrência, distribuição e abundância de peixes na região estuarina de Tramandaí, RS, Brasil. Revista Atlântica, 5, 49-66.

Southwood, T.R.E., 1968. Ecological Methods. London: Chapman \& Hall, $368 \mathrm{p}$.

Spach, H.L.; Santos, C., and Godefroid, R.S., 2003. Padrões temporais na assembléia de peixes na gamboa do Sucuriú, Baía do Paranaguá, Brasil. Revista Brasileira de Zoologia, 20, 591-600.

Spach, H.L.; Santos, C.; Godefroid, R.S.; Nardi, M., and Cunha, F., 2004. A study of the fish community structure in a tidal creek. Brazilian Archives of Biology and Technology, 64, 337-351.

Tongnunui, P.; Ikejima, K.; Yamane, T.; Horinouchi, M.; Medej, T.; Sano, M.; Kurokura, H., and Taniuchi, T., 2002. Fish fauna of the Sikao creek mangrove estuary, Trang, Thailand. Fisheries Science, $68,10-17$.

Vasconcelos Filho, A.L. and Oliveira, A.M.E., 1999. Composição da ictiofauna do Canal de Santa Cruz (Itamaracá-PE, Brasil). Trabalhos Oceanográficos da Universidade Federal de Pernambuco, 27, 101-113.

Vendel, A.L.; Lopes, S.G.; Santos, C., and Spach, H.L., 2003. Fish assemblages in a tidal flat. Brazilian Archives of Biology and Technology, 46, 233-242.

Vendel, A.L.; Santos, C.; Nakayama, P., and Spach, H.L., 2000. O uso de réplica no estudo da ictiofauna de uma planície de maré. Acta Biológica Paranaense, 29, 177-186.

Vendel, A.L.; Spach, H.L.; Lopes, S.G., and Santos, C., 2002. Structure and dynamics of fish assemblages in a tidal creek environment. Brazilian Archives of Biology and Technology, 45, 365-373.

Vieira, J.P. and Musick, J.A., 1993. Latitudinal patterns in diversity of fishes in warm-temperate and tropical estuarine waters of western Atlantic. Revista Atlântica, 15, 115-133.

Vivier, L. and Cyrus, D.P., 2002. Ichthyofauna of the sub-tropical Nhlabane Estuary, KwaZulu-Natal: drought-related changes in the fish community during extended mouth closure. Marine and Freshwater Research, 53, 457-464.

Zar, J.H., 1999. Biostatistical Analysis, 4th edition. Upper Saddle River, New Jersey: Prentice-Hall, 663p. 
$\square$ Resumo $\square$

A Ictiofauna do estuário Saco da Fazenda foi estudada mensalmente entre julho de 2003 e junho de 2004 em quatro áreas definidas em função das características fisiográficas e da representatividade do estuário nesta região. Foram capturados 4502 exemplares, distribuídos em 42 espécies, 35 gêneros e 21 familias. Engraulidae foram os peixes mais abundantes, onde Cetengraulis edentulus dominou nas capturas. As espécies de ocorrência ocasional, representadas, principalmente por indivíduos juvenis, predominaram nas amostragens. As maiores abundâncias ocorreram durante os meses de verão e outono, em contraste com as elevadas biomassas na primavera-outono; sendo que a área IV diferenciou-se das demais, por contribuir com as maiores capturas. Os índices de riqueza, diversidade e equitabilidade, apresentaram padrões semelhantes de flutuação, com valores elevados nos meses de primavera e verão. O índice de Jaccard revelou uma maior similaridade na composição da ictiofauna entre as áreas II e IV, enquanto que a menor ocorreu entre I e IV, provavelmente devido às diferentes áreas destes locais. 